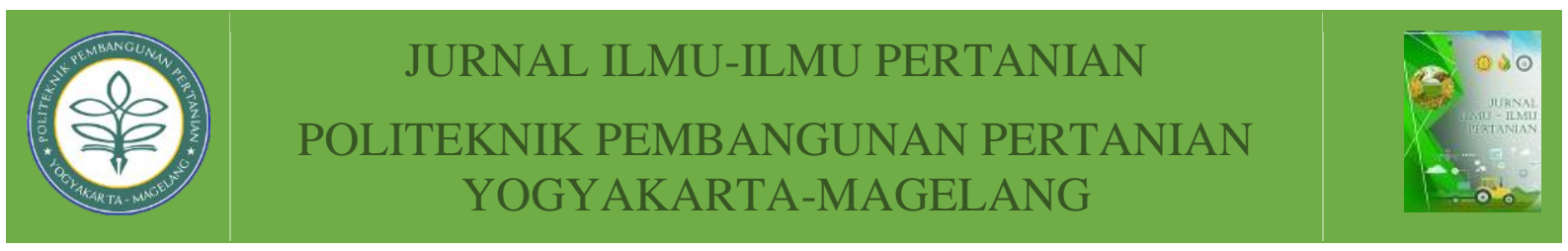

\title{
PENGARUH UMUR BIBIT DAN APLIKASI PGPR TERHADAP PERTUMBUHAN DAN PRODUKSI TANAMAN PADI
}

\author{
Gunawan Permadi ${ }^{1}$, Achmad Nizar $^{2}$, Ainu Rahmi ${ }^{3}$ \\ ${ }^{1}$ Politeknik Pembangunan Pertanian Malang, Malang, 65215 \\ ${ }^{2}$ Politeknik Pembangunan Pertanian Malang, Malang, 65215 \\ ${ }^{3}$ Politeknik Pembangunan Pertanian Malang, Malang 65215
}

Received
Accepted
Published
Copyright Notice
cc)

: $\quad$ March 12 $12^{\text {th }}, 2021$

: $\quad$ March 22 2021

: $\quad$ June $9^{\text {th }}, 2021$

: Authors retain copyright and grant the journal right of first publication with This work is licensed under a Creative Commons Attribution-Non Commercial 4.0 International License.

ABSTRAK: Produksi tanaman padi dipengaruhi oleh umur pindah bibit ke lapangan. PGPR dapat meningkatkan produksi tanaman Padi. Penelitian ini bertujuan untuk melihat pengaruh umur bibit dan aplikasi PGPR pada pertumbuhan dan produksi tanaman padi. Penelitian dilaksanakan di Lahan Praktik Kampus Polbangtan Malang pada bulan Februari sampai dengan bulan Juni 2020. Metode percobaan menggunakan metode rancangan acak kelompok (RAK) faktorial dengan faktor pertama yaitu umur bibit (10,15 dan 20 HSS) dan faktor kedua konsentrasi PGPR (0,7,5,15 ml/liter), sehingga memperoleh 9 kombinasi perlakuan dan diulang 3 kali. Pengamatan dilakukan terhadap tinggi tanaman, jumlah anakan, jumlah anakan produktif dan produksi. Hasil penelitian menunjukkan bahwa perlakuan umur bibit 15 hss dan konsentrasi PGPR $15 \mathrm{ml} /$ liter dapat meningkatkan tinggi tanaman, jumlah anakan, jumlah anakan produktif dan jumlah produksi pada tanaman padi dibandingkan dengan perlakuan lainnya.

Kata kunci: Umur bibit, PGPR, Tanaman Padi.

ABSTRACT: Paddy production is influenced by the age at which the seedlings were transferred to the field. PGPR can increase the production of paddy. This study aims to determine the effect of seedling age and PGPR application on the growth and production of paddy. The research was carried out at the Polbangtan Malang Practice Area from February to June 2020. The experimental method used a factorial randomized block design (RBD) with the first factor, namely the age of the seeds $(10,15$ and 20 day after sowing/das) and the second factor was the concentration of $\operatorname{PGPR}(0,7,5.15 \mathrm{ml} / \mathrm{liter})$, thus obtaining 9 combination treatments and repeated 3 times. Observations were made on plant height, number of tillers, number of productive tillers and production. The results showed that the treatment of 15 das seedling age and $15 \mathrm{ml} /$ liter PGPR concentration could increase plant height, number of tillers, number of productive tillers and total production in rice compared to other treatments. 
Keywords: Age of seedlings, PGPR, Rice Plants.

\section{PENDAHULUAN}

Tanaman Padi (Oryza sativa L.) merupakan salah satu komoditas tanaman pangan yang sangat dibutuhkan sebagian masyarakat. Indonesia merupakan negara dengan jumlah penduduk yang menghadapi tantangan dalam memenuhi kebutuhan pangan (Sution \& Serom, 2019), sehingga perlu adanya kebijakan ketahanan pangan untuk memenuhi kebutuhan. Akan tetapi produksi tanaman padi mengalami penurunan yang diakibatkan peralihan lahan sawah menjadi lahan pemungkiman, serta sebagian petani tidak memperhatikan dalam hal proses budidaya seperti dalam penggunaan umur pindah tanam dan penambahan zat penumbuh lainya.

Pada umumnya proses budidaya tanaman padi dilakukan dengan cara melakukan pindah tanam dari persemaian dan tebar benih langsung. Menurut Porong (2012) bibit padi yang siap pindah tanam apabila memiliki organ tubuh yang lengkap. Dalam penggunaan umur pindah tanam haruslah tepat karena akan mempengaruhi produktivitas dari tanaman padi itu sendiri. Karena perkembangan akar akan terhenti apabila tanaman berumur 42 hari setelah semai sedangkan jumlah anakan produktif akan mencapai maksimal pada tanaman berumur 49-50 hari setelah semai.

Selain penggunaan umur bibit peningkatan produksi tanaman padi dapat dilakukan dengan cara menambahkan PGPR pada saat proses produksi tanaman. PGPR merupakan bakteri yang berkoloni dan hidup pada sekitar perakaran tanaman (Nasib et al., 2016). PGPR diyakini dapat mempengaruhi produktivitas dari tanaman padi. Pengaplikasian PGPR pada tanaman dapat berpengaruh langsung dan tidak langsung.

Pengaruh PGPR secara langsung, yaitu dapat menyediakan dan memobilisasi atau memfasilitasi dalam hal penyerapan unsur hara yang dibutuhkan oleh tanaman dan dapat mensintesis dan mengubah konsentrasi fitohormon pemacu tumbuh tanaman maka tanaman memiliki ketahanan terhadap serangan penyebab penyakit. Sedangkan pengaruh secara tidak langsung, yaitu berkaitan dengan dapat menekan aktivitas patogen dengan menghasilkan berbagai senyawa dan metabolit seperti antibiotik bagi penyebab penyakit terutama patogen tular tanah (Iswati, 2008).

Secara umum penggunaan umur bibit dan aplikasi PGPR dapat meningkatkan pertumbuhan dan produksi tanaman padi. Akan tetapi banyak petani yang belum menerapkan karena belum yakin tentang penggunaan umur bibit padi yang tepat dan aplikasi PGPR pada tanaman padi, dengan demikian peneliti melakukan kajian tentang pengaruh umur bibit padi dan aplikasi PGPR terhadap pertumbuhan dan produksi tanaman padi. karena penelitian tentang penggunaan umur dan aplikasi PGPR sangat penting untuk dapat meningkatkan produktivitas tanaman padi.

\section{METODE}

Penelitian dilaksanakan dilahan kampus Polbangtan Malang pada Bulan Februari sampai Juni 2020. Alat yang digunakan dalam pelaksanaan kajian adalah hand traktor, hand sprayer, timbangan, cangkul, sabit, ember, tali, ajir, tabung ukur, dan alat tulis kantor (ATK). Sedangkan bahan yang digunakan adalah benih padi varietas IR 64, PGPR, pupuk Urea, Pupuk NPK, dan Pupuk kompos

Penelitian ini dilakukan dengan menggunakan Rancangan Acak Kelompok (RAK) faktorial. Faktor pertama yaitu umur bibit dengan 3 taraf dan faktor kedua adalah konsentrasi PGPR dengan 3 taraf, sehingga memperoleh 9 kombinasi perlakuan dan diulang 3 kali. Berikut merupakan perlakuan yang digunakan dalam 
pelaksanaan kajian

Umur Bibit:

- 10 hari setelah semai

- 15 hari setelah semai

- 20 hari setelah semai

Konsentrasi PGPR:

- $0 \mathrm{ml} / \mathrm{liter}$

- $7,5 \mathrm{ml} / \mathrm{liter}$

- $15 \mathrm{ml} / \mathrm{liter}$

Variabel pengamatan yang digunakan dalam proses kajian adalah tinggi tanaman, jumlah anakan, dan jumlah produksi. Sedangkan analisis data yang digunakan untuk melihat perlakuan terbaik yaitu dengan menggunakan uji anova dan uji lanjut dengan menggunakan uji DMRT (Duncan Multiple Range Test) dengan taraf $5 \%$.

\section{HASIL DAN PEMBAHASAN Tinggi Tanaman}

Tidak terdapat perbedaan nyata antar perlakuan umur bibit dan aplikasi PGPR pada tinggi tanaman saat umur tanaman 14, 28, dan 42 hss, namun terdapat interaksi antara perlakuan pada umur 56 dan 70 hss. Rerata tinggi tanaman akibat interaksi perlakuan umur bibit dan konsentrasi PGPR dapat dilihat pada tabel 1.

Tabel 1. Rata-Rata Tinggi Tanaman Akibat Interaksi Perlakuan Umur Bibit dan Konsentrasi PGPR

\begin{tabular}{|c|c|c|c|c|}
\hline \multicolumn{2}{|c|}{ Perlakuan } & \multirow{2}{*}{ Simbol } & \multicolumn{2}{|c|}{$\begin{array}{c}\text { Rata-Rata Tinggi Tanaman }(\mathrm{cm}) \text { Pada } \\
\text { Berbagai Umur (hss) }\end{array}$} \\
\hline Umur Bibit (hss) & $\begin{array}{c}\text { Konsentrasi PGPR } \\
(\mathrm{ml} / \text { liter })\end{array}$ & & 56 & 70 \\
\hline \multirow[t]{3}{*}{10} & 0 & (B1P0) & $62,54 \mathrm{abc}$ & $72,54 \mathrm{abc}$ \\
\hline & 7,5 & (B1P1) & $64,13 \mathrm{bcd}$ & $74,13 \mathrm{bcd}$ \\
\hline & 15 & (B1P2) & 64,54 bcde & 74,54 bcde \\
\hline \multirow[t]{3}{*}{15} & 0 & (B2P0) & $62,13 \mathrm{ab}$ & $72,13 \mathrm{ab}$ \\
\hline & 7,5 & (B2P1) & $69,58 \mathrm{~h}$ & $79,58 \mathrm{~h}$ \\
\hline & 15 & (B2P2) & $70,92 \mathrm{~h}$ & $80,92 \mathrm{~h}$ \\
\hline \multirow[t]{3}{*}{20} & 0 & (B3P0) & $60,63 \mathrm{a}$ & $70,63 \mathrm{a}$ \\
\hline & 7,5 & (B3P1) & 65,79 cdefg & 75,79 cdefg \\
\hline & 15 & (B3P2) & 65,08 bcdef & 75,08 bcdef \\
\hline
\end{tabular}

Keterangan: Angka yang didampingi oleh huruf yang sama pada kolom yang sama tidak berbeda nyata pada Uji DMRT $5 \%$.

Tabel 1 menunjukkan pada variabel pengamatan tinggi tanaman baru terjadi interaksi perlakuan umur bibit dan konsentrasi PGPR pada umur tanaman 56 dan 70 hss. Hal ini terjadi karena adanya pengaruh faktor genetik dan lingkungan, sehingga pada tinggi tanaman tidak berbeda jauh pada umur tanaman $14-42 \mathrm{hss}$. Hal ini sependapat dengan penelitian Jalil et al., (2015) penggunaan umur pindah tanam tidak berpengaruh nyata pada tanaman berumur 15-45 hss. Menurut Anggraini et al. (2013) bahwa terdapat dua faktor yang mempengaruhi proses pertumbuhan, yaitu faktor genetik dan faktor lingkungan. Faktor genetik itu sendiri berkaitan dengan sifat atau perilaku bawaan dari tanaman itu sendiri sedangkan faktor lingkungan berkaitan dengan tempat tumbuh tanaman itu sendiri.

Pada umur tanaman 56 dan 70 hss terdapat interaksi antara perlakuan umur bibit 15 hss dan konsentrasi PGPR 7,5 dan $15 \mathrm{ml} /$ liter mempunyai tinggi tanaman yang lebih baik dibandingkan dengan perlakuan yang lainya. Sedangkan pada perlakuan umur bibit 20 hss dan tanpa perlakuan PGPR menghasilkan tinggi tanaman terendah. Sehingga dengan menggunakan umur bibit 15 hss dan dengan pengaplikasian PGPR pada tanaman dapat meningkatkan tinggi tanaman padi. Hal ini dikarenakan penggunaan umur bibit muda, dapat lebih mudah dalam berinteraksi 
dengan lingkungan yang baru. Amin (2015) menyatakan bahwa umur pindah yang masih muda akan membuat tanaman lebih cepat pulih dan mampu beradaptasi cepat dengan lingkungan sehingga proses pertumbuhan tanaman kearah yang lebih baik. selain itu adanya penambahan PGPR dapat membantu tanaman untuk menyerap unsur hara $\mathrm{N}$ yang dibutuhkan pada saat proses pertumbuhan. Menurut Khalimi \& Wirya (2012) bahwa PGPR dapat secara signifikan mampu meningkatkan tinggi tanaman maksimum, selain itu PGPR mampu melakukan penyerapan dan pemanfaatan unsur hara $\mathrm{N}$ yang dibutuhkan dalam fase vegetatif (Marom et al., 2017).

\section{Jumlah Anakan}

Hasil uji anova menunjukkan bahwa nilai Fhitung < Ftabel artinya tidak terdapat perbedaan nyata antar perlakuan umur bibit dan aplikasi PGPR jumlah anakan saat umur tanaman 14 hss. Sedangkan hasil uji anova memperoleh nilai Fhitung > Ftabel artinya terdapat interaksi perlakuan umur bibit dan aplikasi PGPR pada umur tanaman 28, 42, 56 dan 70 hss, Rerata jumlah anakan akibat interaksi perlakuan umur bibit dan konsentrasi PGPR dapat dilihat pada tabel 2.

Tabel 2. Rata-Rata Jumlah Anakan Akibat Interaksi Perlakuan Umur Bibit dan Konsentrasi PGPR

\begin{tabular}{|c|c|c|c|c|c|c|}
\hline \multicolumn{2}{|c|}{ Perlakuan } & \multirow[b]{2}{*}{ Simbol } & \multicolumn{4}{|c|}{ Rata-Rata Jumlah Anakan Pada Berbagai Umur (hss) } \\
\hline $\begin{array}{l}\text { Umur Bibit } \\
\text { (hss) }\end{array}$ & $\begin{array}{c}\text { Konsentrasi } \\
\text { PGPR } \\
\text { (ml/liter) }\end{array}$ & & 28 & 42 & 56 & 70 \\
\hline \multirow[t]{3}{*}{10} & 0 & $(\mathrm{~B} 1 \mathrm{P} 0)$ & 17,63 abcd & 19,96 abcd & $29,21 \mathrm{a}$ & $30,58 \mathrm{abc}$ \\
\hline & 7,5 & (B1P1) & $17,44 \mathrm{abc}$ & $19,42 \mathrm{ab}$ & 32,75 defg & 32,29 cdef \\
\hline & 15 & (B1P2) & 18,06 bcde & $19,92 \mathrm{abc}$ & $31,08 \mathrm{bcd}$ & 31,17 abcd \\
\hline \multirow[t]{3}{*}{15} & 0 & (B2P0) & $17,13 \mathrm{a}$ & 20,71 bcde & $30,04 \mathrm{ab}$ & $30,38 \mathrm{ab}$ \\
\hline & 7,5 & (B2P1) & $19,50 \mathrm{~g}$ & 21,63 cdefgh & $33,25 \mathrm{efg}$ & $33,25 \mathrm{fgh}$ \\
\hline & 15 & (B2P2) & $20,56 \mathrm{~h}$ & $24,08 \mathrm{i}$ & $34,54 \mathrm{~g}$ & $34,54 \mathrm{~h}$ \\
\hline \multirow[t]{3}{*}{20} & 0 & (B3P0) & $17,31 \mathrm{ab}$ & $18,83 \mathrm{a}$ & $30,25 \mathrm{abc}$ & $30,25 \mathrm{a}$ \\
\hline & 7,5 & (B3P1) & $17,38 \mathrm{abc}$ & 20,71 bcdef & 31,38 bcde & 31,38 abcde \\
\hline & 15 & (B3P2) & 18,06 bcdef & 20,92 bcdefg & $32,33 \mathrm{def}$ & 32,33 cdefg \\
\hline
\end{tabular}

Keterangan: Angka yang didampingi oleh huruf yang sama pada kolom yang sama tidak berbeda nyata pada Uji DMRT $5 \%$.

Pada tabel 2 menunjukkan bahwa pada perlakuan umur bibit 15 hss dan konsentrasi PGPR 15 ml/liter menghasilkan jumlah anakan terbanyak dibandingkan dengan perlakuan yang lainya, sehingga dengan penggunaan umur bibit 15 hss dan konsentrasi PGPR $15 \mathrm{ml} / \mathrm{liter}$ dapat meningkatkan jumlah anakan pada setiap tanaman Hal ini dikarenakan penggunaan umur bibit lebih muda ( $<15 \mathrm{hss})$ lebih cepat dalam masa dormansi, sehingga dalam menghasilkan anakan lebih cepat. Menurut Kumalasari et al. (2017) bahwa penggunaan bibit tanaman padi umur muda menyebabkan bibit tersebut lebih cepat beradaptasi dengan lingkungan tumbuh, mempunyai perakaran yang lebih baik dan dalam, sehingga lebih efektif memanfaatkan hara dan dapat tumbuh lebih baik. Selain itu juga dalam proses pembentukan anakan memerlukan unsur hara terutama unsur hara N. Oleh karena itu dengan pengaplikasian PGPR dapat membantu tanaman dalam menyerap unsur hara $\mathrm{N}$ yang ada di dalam tanah maupun di udara. PGPR mampu melakukan penyerapan dan pemanfaatan unsur hara $\mathrm{N}$ yang dibutuhkan dalam fase vegetatif (Lindung, 2014). Sehingga dengan adanya PGPR pada proses budidaya tanaman padi dapat memaksimalkan tanaman dalam melakukan penyerapan unsur hara yang ada di dalam tanah. 


\section{Jumlah Anakan Produktif}

Hasil uji anova menunjukkan F hitung $>\mathrm{F}$ tabel artinya terdapat interaksi perlakuan umur bibit dan aplikasi PGPR memiliki perbedaan nyata antar perlakuan pada jumlah anakan produktif, Rerata jumlah anakan produktif akibat interaksi perlakuan umur bibit dan Konsentrasi PGPR dapat dilihat pada tabel 3.

Tabel 3. Rata-Rata Jumlah Anakan Produktif Akibat Interaksi Perlakuan Umur Bibit dan Konsentrasi PGPR

\begin{tabular}{cccc}
\hline Umur Bibit & $\begin{array}{c}\text { Perlakuan } \\
\text { Konsentrasi PGPR } \\
(\text { m1/Liter })\end{array}$ & Simbol & Rata-Rata Jumlah Jumlah Anakan Produktif \\
\hline 10 & 0 & B1 P0 & 27.58 abc \\
& 7,5 & B1 P1 & 29.29 cdef \\
15 & 15 & B1 P2 & 28.17 abcd \\
& 0 & B2 P0 & 27.38 ab \\
20 & 7,5 & B2 P1 & 30.25 fgh \\
& 15 & B2 P2 & 31.54 h \\
& 7,5 & B3 P0 & 27.25 a \\
& 15 & B3 P2 & 28.38 abcde \\
\hline
\end{tabular}

Keterangan: Angka yang didampingi oleh huruf yang sama pada kolom yang sama tidak berbeda nyata pada Uji DMRT 5\%.

Pada tabel 3 menunjukkan menunjukkan bahwa pada perlakuan umur bibit $15 \mathrm{ml} /$ liter dan konsentrasi PGPR 7,5 $\mathrm{ml} /$ liter dan $15 \mathrm{ml} /$ liter memperoleh hasil jumlah anakan tertinggi dibandingkan dengan perlakuan yang lainnya. Hal ini dikarenakan pada umur pindah tanam yang relatif muda dapat melakukan pertumbuhan jumlah anakan yang relatif lebih cepat dan dapat menumbuhkan jumlah anakan yang lebih aktif. Selain itu menurut Marlina et al., (2018) bahwa umur pindah tanam 14 hari setelah tanam merupakan waktu yang cukup bagi tanaman padi untuk beradaptasi dengan baik terhadap lingkungan tumbuh dan masih memiliki cadangan makanan sehingga tanaman padi tersebut dapat tumbuh dan menghasilkan bobot gabah terberat. Menurut teori phyllochron, peluang untuk membentuk lebih banyak anakan akan lebih besar jika pindah tanam bibit dilakukan pada umur yang lebih muda dan persemaian yang juga tidak tergenang, seperti komponen utama teknik SRI, selain itu jumlah anakan produktif ditentukan oleh jumlah anakan yang tumbuh sebelum mencapai fase primordia (Wangiyah et al., 2009). Anakan produktif pada tanaman padi memerlukan unsur hara $\mathrm{P}$ dalam pembentukan bulir dalam setiap malai. PGPR diyakini dapat membantu penyerapan unsur hara $\mathrm{P}$ yang dibutuhkan dari tanaman padi. Menurut Anhar et al., (2011) aktivitas Pf dalam rizosfer dapat meningkatkan kemampuan tanaman menyerap unsur $\mathrm{P}$ dan $\mathrm{N}$, memacu jaringan meristem pada titik tumbuh, dan menyediakan metabolit pengatur tumbuh pada tanaman.

\section{Jumlah Produksi}

Hasil uji anova memperoleh nilai $\mathrm{F}$ hitung > F tabel artinya terdapat interaksi perlakuan umur bibit dan aplikasi PGPR artinya memiliki perbedaan nyata antar perlakuan pada jumlah produksi, Rerata jumlah produksi akibat interaksi perlakuan umur bibit dan konsentrasi PGPR dapat dilihat pada tabel 4 . 


\begin{tabular}{cccc}
\multicolumn{2}{c}{ Tabel 4 Rata-Rata Jumlah Produksi Akibat Interaksi Perlakuan Umur Bibit dan Konsentrasi PGPR } \\
\hline $\begin{array}{c}\text { Perlakuan Umur } \\
\text { Bibit (hss) }\end{array}$ & $\begin{array}{c}\text { Perlakuan } \\
\text { Konsentrasi PGPR } \\
\text { (m1/liter) }\end{array}$ & Simbol & Rata-Rata Jumlah Produksi (gram) \\
\hline 10 & 0 & (B1P0) & 89,93 a \\
& 7,5 & (B1P1) & 98,40 bc \\
15 & 15 & (B1P2) & $96,01 \quad$ b \\
& 0 & (B2P0) & 110,89 fg \\
& 7,5 & (B2P1) & 133,00 h \\
20 & 15 & (B2P2) & 141,79 i \\
& 0 & (B3P0) & 106,35 def \\
& 7,5 & (B3P1) & 99,52 bcd \\
& 15 & (B3P2) & 101,43 bcde \\
\hline
\end{tabular}

Keterangan: Angka yang didampingi oleh huruf yang sama pada kolom yang sama tidak berbeda nyata pada Uji DMRT $5 \%$.

Pada tabel 4 menunjukkan bahwa pada perlakuan umur bibit 15 hss dan konsentrasi PGPR $15 \mathrm{ml} /$ liter menghasilkan jumlah produksi tertinggi dibandingkan dengan perlakuan yang lainnya, yaitu 141,79 gram. Sehingga dengan penggunaan umur bibit 15 hss dan konsentrasi PGPR 15 ml/liter dapat meningkatkan jumlah produksi. Hal ini dikarenakan dengan menggunakan umur bibit 15 hss dan konsentrasi PGPR 15 $\mathrm{ml} /$ liter dapat meningkatkan jumlah anakan. Sebab jumlah produksi dapat dipengaruhi oleh banyaknya jumlah anakan, karena semakin banyak jumlah anakan maka semakin banyak jumlah produksi yang dihasilkan. Menurut Jalil et al, (2015) bahwa penggunaan umur bibit muda memiliki kemampuan beradaptasi yang lebih baik dibandingkan dengan bibit tua sehingga tanaman dapat tumbuh lebih baik dan juga dapat berpengaruh terhadap produksi. Menurut Napisah \& Ningsih (2014) bahwa penggunaan umur pindah tanam 15 hss menghasilkan jumlah anakan yang signifikan. Akan tetapi penggunaan umur bibit yang masih muda (5-15 hari) sangat beresiko karena masih lemah dan perakaran yang belum kuat namun berpotensi anakan dan pertumbuhan tanaman yang tinggi, sedangkan umur bibit yang jauh lebih tua (>25 hari) akan menurunkan produksi (Siregar 1891). Sedangkan menurut Taufik (2010) bahwa peran PGPR dalam meningkatkan pertumbuhan tanaman diduga berhubungan dengan kemampuan mensintesis hormon tumbuh, memfiksasi nitrogen dan melarutkan fosfat. Sehingga dengan penggunaan umur pindah tanam 15 hss dan penggunaan konsentrasi PGPR $15 \mathrm{ml} /$ liter dapat meningkatkan produksi tanaman padi.

\section{SIMPULAN DAN SARAN}

Perlakuan umur bibit dan aplikasi PGPR pada parameter pengamatan tinggi tanaman tidak beda nyata pada umur tanaman 14-42 hst. tetapi terdapat perbedaan yang nyata pada umur tanaman 56-70 hst. Pada perlakuan umur bibit 15 hss dan konsentrasi PGPR 15 ml/liter menghasilkan tinggi tanaman yang signifikan atau menghasilkan tinggi tanaman tertinggi.

Perlakuan umur bibit dan aplikasi PGPR berpengaruh nyata terhadap parameter pengamatan jumlah anakan pada umur tanaman 28-70 hst, tetapi tidak berpengaruh nyata pada umur tanamn 14 hst. Perlakuan umur bibit 15 hss dan konsentrasi PGPR $15 \quad \mathrm{ml} / \mathrm{liter}$ menghasilkan jumlah anakan tertinggi dari pada perlakuan yang lainya.

Pada perlakuan umur bibit dan aplikasi PGPR berpengaruh nyata terhadap jumlah anakan produktif. Pada perlakuan umur bibit 15 hss dan konsentrasi PGPR 
sebanyak 7,5 ml/liter dan $15 \mathrm{ml} /$ liter menghasilkan jumlah anakan tertinggi dibandingkan dengan perlakuan yang lainya, yaitu 31,54 (B2P2).

Perlakuan umur bibit dan aplikasi PGPR berpengaruh nyata pada jumlah produksi tanaman padi. Pada perlakuan umur bibit 15 hss dan konsentrasi PGPR 15 $\mathrm{m} /$ liter menghasilkan jumlah produksi tertinggi.

\section{PUSTAKA ACUAN}

Amin, M. (2015). Pengaruh Umur Pindah Tanam dan Jumlah Bibit Per Lubang Tanam Terhadap Pertumbuhan Tanaman Padi (Oryza sativa L.). Skripsi . Fakultas Pertanian. Universitas Teuku Umar Meulaboh. Aceh Barat.

Anggraini, F., Suryanto, A., \& Aini, N. (2013). Sistem Tanam dan Umur Bibit Pada Tanaman Padi Sawah ( Oryza sativa L .) Varietas INPARI 13. Jurnal Produksi Tanaman, 1(2), 52-60.

Anhar, A., Doni, F., \& Advinda, L. (2011). Respons Pertumbuhan Tanaman Padi (Oryza sativa L.) Terhadap Introduksi Pseudomonas fluoresen. Eksakta, 1(12), 1-11.

Iswati, R. (2008). Pengaruh Dosis Formula PGPR Asal Perakaran Bambu Terhadap Pertumbuhan Tanaman Tomat (Solanum lycopersicum syn ). Jurnal Agroteknotropika, 1(1), 9-12.

Jalil, M., Nurba, D., \& Subandar, I. (2015). Pengaruh Umur Pindah Tanam dan Jumlah Bibit Per Lubang Tanam Terhadap Pertumbuhan dan Produksi Padi (Oryza sativa L.). Jurnal Agrotek Lestari, 1(1), 55-66. https://doi.org/10.1017/CBO9781107 415324.004

Khalimi, K., \& Wirya, G. N. A. S. (2012). Pemanfaatan Plant Growth Promoting Rhizobacteria Untuk Biostimulants Dan Bioprotectants. Ecotrophic: Journal of Environmental Science,

\section{4(2), 131-135.}

Kumalasari, S. N., Sudiarso, \& Suryanto, A. (2017). Pengaruh Jarak Tanam dan Jumlah Bibit Pada Tanaman Padi (Oryza Sativa L) Hibrida Varietas PP3. Jurnal Produksi Tanaman, 5(7), 1220-1227.

Lindung. (2014). Teknologi Pembuatan Dan Aplikasi Bakteri Pemacu Pertumbuhan Tanaman (Pgpr) dan Zat Pengatur Tumbuh (Zpt). https://doi.org/10.1017/CBO9781107 415324.004

Marlina, N., Gusmiatun, Aminah, I. S., \& Wahyuni, A. (2018). Aplikasi Umur Pindah Tanam Pada 2 Varietas Padi Lokal (Oryza Sativa L.) Di Tanah Rawa. Jurnal Agriculture, 12(1), 4248.

Marom, N., Rizal, F., \& Bintoro, M. (2017). Uji Efektivitas Saat Pemberian dan Konsentrasi PGPR (Plant Growth Promoting Rhizobacteria) Terhadap Produksi dan Mutu Benih Kacang Tanah (Arachis hypogaea L.). Agriprima, Journal of Applied Agricultural Sciences, 1(2), 174-184. https://doi.org/10.25047/agriprima.v1 i2.43

Napisah, K., \& Ningsih, R. D. (2014). Pengaruh Umur Bibit Terhadap Produktivitas Padi Varietas INPARI 17. Prosiding Seminar Nasional "Inovasi Teknologi Pertanian Spesifik Lokasi”, Banjarbaru, 4, 127-132.

Nasib, S. Bin, Suketi, K., \& Widodo, W. D. (2016). Pengaruh Plant Growth Promoting Rhizobacteria Terhadap Bibit dan Pertumbuhan Awal Pepaya. Buletin Agrohorti, 4(1), 63. https://doi.org/10.29244/agrob.4.1.63 $-69$

Porong, V. J. (2012). Perbedaan Umur Bibit Terhadap Pertumbuhan dan Produksi Padi Sawah ( Oryza sativa L). Ugenia, 18(1), 35-40.

Sution, \& Serom. (2019). Pengaruh Umur Bibit dan Jumlah Bibit Terhadap 
Produktivitas Padi Sawah. Jurnal Pertanian Agros, 21(1), 100-107.

Taufik, M. (2010). Pertumbuhan dan Produksi Tanaman Cabai yang Diaplikasi Plant Growth Promoting Rhizobacteria. J. Agrivigor, 10(1), 99-107.

Wangiyah, W., Laiwan, Z., \& Sanisah. (2009). Pertumbuhan dan Hasil
Tanaman Padi Varietas Ciherang Dengan Teknik Budidaya "Sri (System Of Rice Intensification)" pada Berbagai Umur dan Jumlah Bibit Per Lubang Tanam. Crop Agro, 2(1), 7078.

https://cropagro.unram.ac.id/index.ph p/caj/article/view/37/28

\section{DOI :}

